\title{
PENATALAKSANAAN TREMOR TERKINI
}

\author{
Rizal Tumewah \\ Bagian Neurologi Fakultas Kedokteran \\ Universitas Sam Ratulangi /RSUP Prof. Dr. R.D. Kandou Manado \\ Email: rizaltung@yahoo.com
}

\begin{abstract}
Not all tremors are Parkinson's neither pathologic. Some of the tremor therapies have small advantage and some not at all. Therefore, with the better understanding of the causes of tremor, therapists can determine the most effective and minimal adverse effects of therapies. Tremor is the most frequently symptom that can be detected on the movement disorder group. Characteristics of tremor are: rhythmic, oscillatory movement of hands, head, neck or trunk; voice trembling; difficulties in writing and drawing; and problems in holding or controlling things. Tremor can be evoked in a normal state, pathologic conditions, such as psychogenic, metabolic, drug-induce and toxicity conditions, as well as in idiopathic conditions; thus, the therapies have to be various depended on the causes. Occasionally, symptomatic medical therapies can be given to the specific type of tremor. Surgical treatments like thalamotomy, pallidotomy, and thalamic stimulation may be used to treat severe or disabling tremor which is failed with medical treatment. Current treatment of tremor based on Consensus of Movement Disorder Society emphasized the need to classified tremors based on the etiopathogenesis, clinical features, and additional examination in order to achieve more favorable outcome in tremor treatment.
\end{abstract}

Keywords: tremor, current treatment, etiopathogenesis, clinical features, additional examination, medical and surgical treatment

\begin{abstract}
Abstrak: Tidak semua tremor itu Penyakit Parkinson dan tidak semua tremor itu patologik. Umumnya terapi tremor tidak terlalu bermanfaat dan kadang tidak ada perbaikan. Dengan adanya pemahaman mengenai penyebab tremor, para klinikus dapat memberikan terapi yang efektif dengan efek samping minimal. Tremor merupakan salah satu gejala yang paling sering ditemukan dari kelompok movement disorders. Karakteristik tremor dapat berupa getaran yang berirama pada tangan, lengan, kepala, leher, atau tubuh; suara bergetar; kesulitan menulis dan menggambar; serta bermasalah dalam memegang dan mengontrol benda. Tremor dapat ditemukan pada keadaan normal, keadaan patologik akibat psikogenik, penyakit pada sistem saraf, metabolik, obat-obatan, keracunan, bahkan idiopatik sehingga terapinya pun bervariasi tergantung dari penyebab. Kadang terapi medikamentosa simptomatik dapat diberikan pada tipe tremor tertentu. Pembedahan seperti thalamotomy, pallidotomy, dan thalamic stimulation biasanya dilakukan pada kasus tremor yang berat atau gagal dalam pengontrolan dengan terapi medikamentosa. Terapi tremor terkini berdasarkan konsensus Movement Disorder Society menekankan perlunya pendekatan klasifikasi tremor berdasarkan etiopatogesis, gejala klinis, dan pemeriksaan penunjang untuk menentukan keberhasilan dalam menangani pasien tremor.
\end{abstract}

Kata kunci: tremor, terapi terkini, etiopatogenesis, gejala klinis dan pemeriksaan penunjang, medikamentosa, pembedahan

Tremor ialah serentetan gerakan involunter, ritmis, berbentuk getaran, pada satu atau lebih bagian tubuh. Gerakan ini timbul akibat berkontraksinya otot-otot yang berlawanan secara bergantian atau irregular dengan frekuensi dan amplitudo tetap 
dalam periode waktu yang lama. ${ }^{1-4}$ Tremor merupakan gangguan gerakan yang paling sering ditemukan. Insiden dan prevalensinya meningkat sejalan peningkatan usia. Lebih dari $4 \%$ pasien dengan usia diatas 65 tahun mengalami gangguan gerak ini dimana 2/3 populasi diantaranya mengalami tremor pergelangan tangan sehingga menyebabkan gangguan fungsional dan sosial dalam kehidupan sehari-hari. ${ }^{1,2}$

\section{KLASIFIKASI TREMOR}

Secara umum, tremor dibagi atas tremor normal (fisiologis) dan abnormal (patologik). Tremor fisiologis terjadi pada semua kelompok otot saat berkontraksi dalam keadaan sadar dan dalam fase tidur pada tingkat tertentu. Getarannya tidak dapat dilihat dengan mata, frekuensi antara 8-13 Hz. Tremor ini juga berhubungan dengan kelelahan, ketakutan, emosi, kesadaran, rasa panas, rasa dingin, medikasi, alkohol, dan penggunaan obatobatan. Tremor abnormal dapat diklasifikasikan berdasarkan lokasi, frekuensi, amplitudo, ritmisitas, hubungan antara keadaan istirahat dan pergerakan, etiologi, dan berdasarkan perubahan patologik. Tremor bisa terjadi unilateral maupun bilateral. Tremor paling sering didapatkan pada extremitas bagian distal jari-jari dan tangan. Frekuensi tremor bisa lambat (3-5 $\mathrm{Hz})$, sedang $(5-8 \mathrm{~Hz})$, atau cepat $(9-12 \mathrm{~Hz})$. Amplitudo tremor bisa kasar, sedang, atau halus. Tremor bisa konstan atau intermiten dan bisa ritmis atau relatif nonritmis. ${ }^{3,5,6}$

Klasifikasi tremor berdasarkan
gambaran klinisnya: ${ }^{2,6-9}$

1. Tremor istirahat (resting/static tremor): Tremor yang timbul pada bagian tubuh yang ditopang melawan gravitasi dan tidak ada aktivitas otot volunter (tidak ada kontraksi otot skelet). Amplitudo meningkat selama stress atau dengan gerakan umum (berjalan), dan berkurang dengan gerakan menunjuk sasaran (tes telunjuk-hidung). Tremor istirahat dapat ditemukan pada parkinsonisme, alcohol withdrawal, tremor esensial, dan neurosifilis. $^{6-9}$

2. Tremor aksi (action tremor): Merupakan tremor yang terjadi akibat kontraksi otot volunter. Tremor aksi meliputi parkinsonisme, tremor esensial, penyakit serebelar, tremor Holmes, tremor fisiologis, obat-obatan (kecuali yang menyebabkan Parkinson). Tremor aksi dibagi atas:

a. Tremor postural: terjadi pada bagian tubuh yang mempertahankan posisi melawan gravitasi.

b. Tremor kinetik: terjadi pada gerakan volunter. Tremor kinetik terbagi 3 yaitu :

- Tremor intensi: Merupakan tremor yang terjadi pada gerakan menunjuk sasaran dengan amplitudo yang semakin meningkat saat gerakan mendekati sasaran pada akhir gerakan.

- Task-spesific tremor: merupakan tremor kinetik yang muncul atau dipicu oleh aktivitas tertentu yang membutuhkan ketrampilan, seperti menulis, berbicara, memainkan musik instrumental (tremor okupasi).

- Tremor kinetik sederhana (simple kinetic tremor): Tremor yang berhubungan dengan pergerakan ekstremitas, seperti gerakan pronasi-supinasi atau fleksiekstensi pergelangan tangan.

c. Tremor isometrik: Tremor yang terjadi pada kontraksi otot volunter melawan suatu tahanan konstan, seperti mendorong dinding, menekan telapak tangan pemeriksa.

Klasifikasi tremor dapat membantu dalam menentukan penyebab, sindromsindrom tremor bervariasi. Walaupun demikian pada pemeriksaan pasien dengan tremor perlu dipertimbangkan aspek riwayat penyakit dan pemeriksaan fisik neurologis. $^{7}$ Klasifikasi dan karakteristik tremor dapat dilihat pada Tabel 1. 
Tabel 1. Klasifikasi dan karakteristik tremor ${ }^{7}$

\begin{tabular}{cclll}
\hline Jenis tremor & \multicolumn{1}{c}{ Frekuensi } & \multicolumn{1}{c}{ Amplitudo } & \multicolumn{1}{c}{ Kejadian } & \multicolumn{1}{c}{ Contoh } \\
\hline Tremor istirahat & $\begin{array}{l}\text { Rendah s/d sedang } \\
(3-6 \mathrm{~Hz})\end{array}$ & $\begin{array}{l}\text { Tinggi, berkurang } \\
\text { pada gerakan } \\
\text { menunjuk sasaran }\end{array}$ & $\begin{array}{l}\text { Tangan ditopang } \\
\text { melawan gravitasi, otot } \\
\text { tidak beraktivitas }\end{array}$ & $\begin{array}{l}\text { Penyakit Parkinson, } \\
\text { parkinsonisme yang dipicu } \\
\text { obat-obatan (neuroleptik, } \\
\text { metoklopramide [Reglan]) }\end{array}$ \\
\hline Tremor aksi & - & \multicolumn{1}{c}{-} & Kontraksi otot volunteer & \\
\hline Tremor postural & $\begin{array}{l}\text { Sedang s/d tinggi } \\
(4-12 \mathrm{~Hz})\end{array}$ & $\begin{array}{l}\text { Rendah, meningkat } \\
\text { dengan gerakan } \\
\text { volunteer }\end{array}$ & $\begin{array}{l}\text { Mempertahankan posisi } \\
\text { melawan gravitasi }\end{array}$ & $\begin{array}{l}\text { Tremor fisiologis, tremor } \\
\text { esensial, gangguan } \\
\text { metabolik, drug atau alcohol } \\
\text { withdrawal }\end{array}$ \\
\hline $\begin{array}{c}\text { Kremor kinetik } \\
\text { sederhana }\end{array}$ & Variasi (3-10 Hz) & $\begin{array}{l}\text { Tidak berubah pada } \\
\text { gerakan menunjuk } \\
\text { sasaran }\end{array}$ & $\begin{array}{l}\text { Gerakan sederhana pada } \\
\text { ekstremitas }\end{array}$ & \\
\hline Intensi & Rendah $(<5 \mathrm{~Hz})$ & $\begin{array}{l}\text { Meningkat pada } \\
\text { gerakan menunjuk } \\
\text { sasaran }\end{array}$ & $\begin{array}{l}\text { Gerakan menunjuk } \\
\text { sasaran }\end{array}$ & $\begin{array}{l}\text { Lesi serebelum (stroke, } \\
\text { sklerosis multipel,tumor); } \\
\text { drug-induced (lithium, } \\
\text { alcohol) }\end{array}$ \\
\hline $\begin{array}{c}\text { Tremor isometrik } \\
\text { Task-spesific }\end{array}$ & Sedang & Variasi & $\begin{array}{l}\text { Kontraksi otot melawan } \\
\text { tahanan konstan }\end{array}$ & $\begin{array}{l}\text { Memegang benda berat pada } \\
\text { satu tangan }\end{array}$ \\
\hline tremor & Variasi $(4-10 \mathrm{~Hz})$ & Variasi & $\begin{array}{l}\text { Terjadi pada aksi } \\
\text { tertentu }\end{array}$ & Menulis, main musik \\
\hline
\end{tabular}

\section{DIAGNOSIS TREMOR}

Deskripsi tremor sebaiknya termasuk aspek-aspek: 1) topografi tremor (kepala, dagu, rahang, pita suara, ekstremitas atas/bawah, tubuh, dll); 2) kondisi aktivasi tremor (istirahat, postur, gerakan tanpa sasaran tujuan, gerakan menuju sasaran, pekerjaan khusus); dan 3) frekuensi tremor. Tidak ada pemeriksaan laboratorium untuk menentukan diagnosis pada beberapa penyebab tremor. Pemeriksaan fisik yang seksama merupakan alat diagnostik yang paling baik. Pemeriksaan neurologis yang seksama untuk mengevaluasi sistem saraf motorik dan sensorik, sistem ekstrapiramidal, dan fungsi serebelum sangat diperlukan untuk menentukan lokasi anatomis tremor, tipe tremor, dan tingkat keparahan (skala 0-10) (Gambar 1).,7,9 Pemeriksaan penunjang yang dapat dilakukan meliputi darah rutin, kimia darah, fungsi tiroid, fungsi hati, vitamin B12, kadar tembaga dalam urin selama 24 jam dan ceruloplasmin serum. Oleh karena itu dibuat algoritma untuk mengevaluasi tremor (Gambar 2). 2,4,7

Pemeriksaan cairan serebrospinal perlu dilakukan untuk mendeteksi IgG oligoklonal jika dicurigai sklerosis multipel. Rekaman elektromiografi (EMG) dapat digunakan untuk menilai frekuensi tremor dan pola kontraksi antara otot-otot agonis dan antagonis.
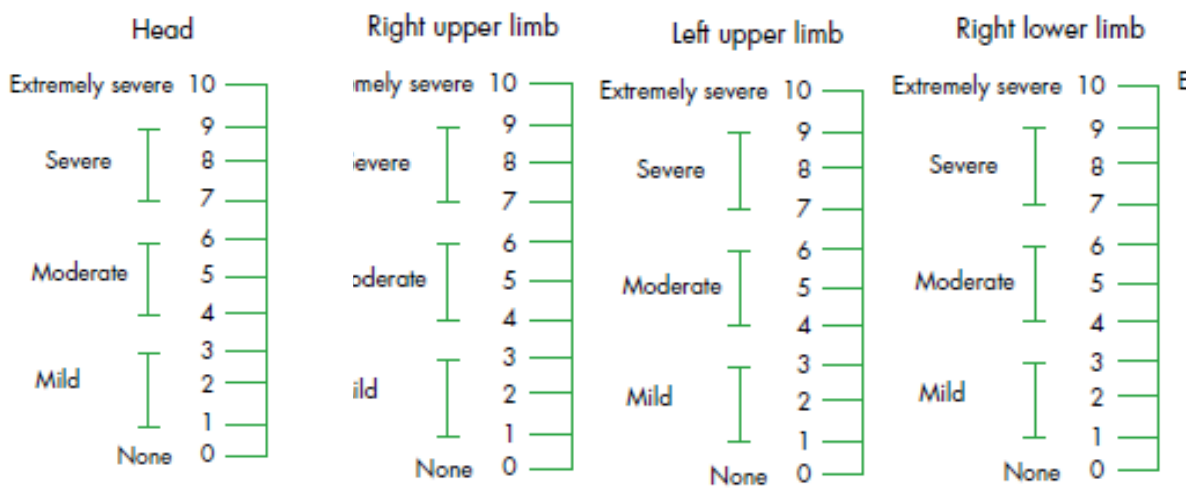

Left lower limb

Gambar 1. Skala validasi (0-10) untuk menentukan keparahan tremor ${ }^{8}$ 


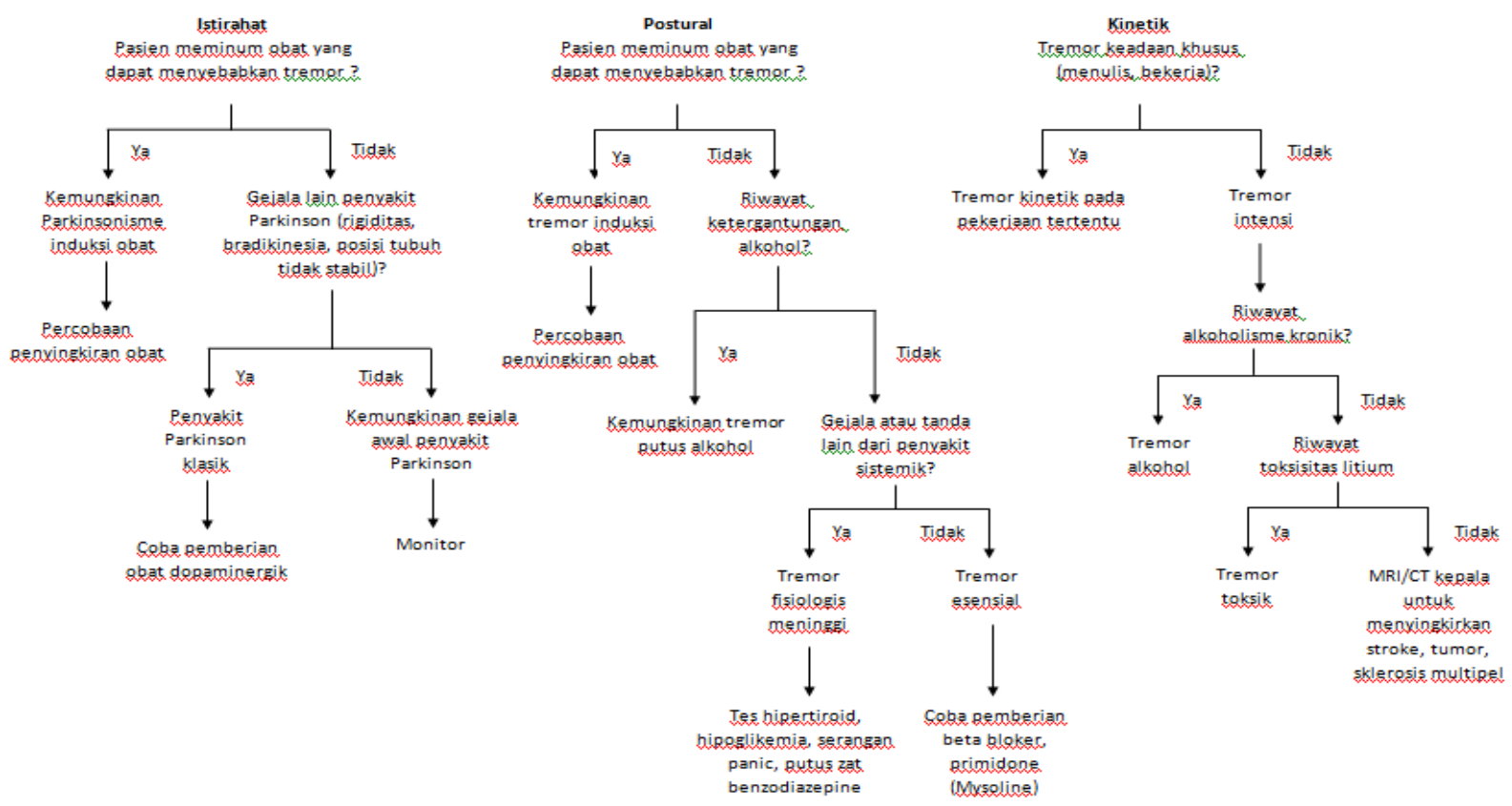

Gambar 2. Algoritma untuk mengevaluasi tremor. (MRI= magnetic resonance imaging, $\mathrm{CT}=$ computed tomography) ${ }^{7}$

Pemeriksaan computed tomography (CT-scan) atau magnetic resonance imaging (MRI) dapat dilakukan jika dicurigai adanya tremor intensi, tumor, stroke, sklerosis multipel. Pada penyakit Parkinson, pemeriksaan Positron emission tomography (PET) dapat dilakukan untuk menunjukkan pemendekan sinyal yang tinggi antara nukleus rubra dan substansia nigra. Single photon emission computed tomography (SPECT)-scan digunakan untuk membedakan tremor esensial dan tremor dominan pada penyakit Parkinson. $^{2,4,7}$

\section{SINDROM TREMOR}

Sindrom tremor dapat dibagi atas tremor normal, tremor esensial, tremor Parkinson, tremor sereberalis, tremor ortostratik primer, tremor distonia, tremor Holmes, tremor akibat induksi obat dan intoksikasi, tremor neuropatik, dan tremor psikogenik.

\section{Tremor normal}

Tremor normal terdiri atas tremor fisiologis dan enhanced physiologic tremor
(EPT). Tremor fisiologis dapat ditemukan pada setiap orang, merupakan tremor aksi postural ringan, dengan amplitudo rendah, frekuensi tinggi, pada tangan antara 6-12 Hz. Biasanya tidak kelihatan.. ${ }^{2,4,7,8,9}$

EPT merupakan salah satu tipe tremor postural yang memiliki frekuensi yang sama dengan tremor fisiologis namun dengan amplitudo yang lebih besar. Biasanya terlihat pada posisi tangan direntangkan pada sisi tubuh pada keadaan takut dan cemas, gangguan metabolik (hipertiroid, tirotoksikosis, hiperkortisolisme, hipoglikemi), feokromositoma, latihan fisik intens, alcohol withdrawal, obat sedatif, dan efek toksik dari beberapa obat-lithium, asam nikotinat, xanthines (kopi, teh, aminofilin, cola), dan kortikosteroid. Karakteristik tremor ini ialah tremor menghilang jika faktor pemicu atau faktor yang mendasari dihindari. ${ }^{2-4,8}$ Penatalaksanaan EPT dimulai dengan mengendalikan rasa takut atau cemas, atau pemicu dari tremor tersebut. Walaupun pengobatan kausal tidak dapat menekan tremor dengan baik, propanolol dan golongan $\beta$-bloker lainnya direkomendasikan. Dosis obat-obat yang dapat 
diberikan pada tremor fisiologis meninggi yaitu propanolol $160 \mathrm{mg} / \mathrm{hari}$, atenolol 200 $\mathrm{mg} /$ hari, metoprolol $200 \mathrm{mg} /$ hari, nadolol 80 mg/hari, timolol 20 mg/hari. Pemberian alkohol juga dapat mengurangi gejala tremor fisiologis meninggi. ${ }^{4,15,18}$

\section{Tremor esensial}

Tremor esensial (tremor herediter, tremor familial, tremor esensial benigna) merupakan tremor aksi bilateral pada tangan, lengan, dan kepala yang berkembang progresif lambat dalam waktu sedikitnya 3 tahun. Onset tremor meningkat pada usia dekade kedua dan keenam dan mengenai $95 \%$ pada tangan dengan frekuensi rendah dari kaki, 34\% kepala, $20 \%$ kaki, $12 \%$ suara, $5 \%$ wajah dan $5 \%$ pada badan. Frekuensi tremor 4-12 Hz. Dengan amplitudo meningkat dengan stress, kelelahan, dan obat-obatan seperti stimulant SSP, dan pada aktivitas volunter seperti memegang garpu atau cangkir. Etiologi dan patofisiologi tremor esensial belum pasti. Sekitar 50\% tremor esensial disertai riwayat keluarga, yang merupakan penyakit autosomal dominan. ${ }^{8,10,12}$

Tabel 2 merupakan pedoman diagnosis tremor esensial menurut Movement Disorder Society, yang menentukan tremor esensial 'pasti', 'sangat mungkin', dan 'mungkin.' 6,7,9-11

Tabel 2. Pedoman untuk diagnosis tremor esensial ${ }^{4,12}$

\begin{tabular}{|c|c|c|}
\hline Kriteria inti & Kriteria sekunder & Red flags \\
\hline $\begin{array}{l}\text { 1. Tremor aksi bilateral pada } \\
\text { tangan dan lengan atas (tetapi } \\
\text { bukan tremor istirahat) }\end{array}$ & 1. Durasi lama (> 3 tahun) & $\begin{array}{l}\text { 1. Tremor unilateral, tremor } \\
\text { fokal, tremor kaki, kelainan } \\
\text { gaya berjalan, rigiditas, } \\
\text { bradikinesia, tremor } \\
\text { istirahat }\end{array}$ \\
\hline $\begin{array}{l}\text { 2. Tidak ada tanda neurologis yang } \\
\text { lain kecuali fenomena roda gigi }\end{array}$ & 2. Riwayat keluarga & 2. Onset tiba-tiba atau cepat \\
\hline $\begin{array}{l}\text { 3. Bisa ada tremor kepala tanpa } \\
\text { sikap yang abnormal. }\end{array}$ & 3. Berespon terhadap etanol & $\begin{array}{l}\text { 3. Obat yang digunakan saat } \\
\text { ini dapat menyebabkan } \\
\text { atau mencetuskan tremor } \\
\text { 4. Bisa ada tremor kepala } \\
\text { dengan sikap yang } \\
\text { abnormal (head tilt atau } \\
\text { berbalik) }\end{array}$ \\
\hline
\end{tabular}

Tremor esensial klasik dapat disebabkan adanya abnormalitas pada segitiga Guillain-Mollaret (nukleus ruber, nukleus oliva, dan serebelum). ${ }^{4,9,10}$ Tremor esensial non-klasik atau tremor esensial tak terklasifikasi ialah tremor yang disertai gejala-gejala neurologis lainnya, seperti ataksia, bradikinesia ringan, atau hipomimia; atau menjadi tremor istirahat. Hal ini dapat disalah diagnosis dengan penyakit Parkinson, namun pada tremor esensial, tonus otot dan kekuatan otot normal. $^{4,9}$

Penatalaksanaan pada tremor esensial dapat dilakukan dengan beberapa terapi seperti simtomatik, kuratif, atau neuroprotektif walaupun tremor tidak dapat dihilangkan. Pada terapi simtomatik, medikasi sebaiknya dimulai dengan dosis kecil dan ditingkatkan perlahan-lahan sampai dosis maksimal atau tampak efek terapinya.

Berdasarkan parameter praktis untuk pengobatan tremor esensial yang dipublikasikan oleh the American Academy of Neurology dinyatakan pengobatan lini pertama tremor esensial meliputi propanolol (Inderal) (60-800 $\mathrm{mg} /$ hari) dengan dosis awal $30 \mathrm{mg} / \mathrm{hari}$, dan dapat diberikan dalam jangka panjang. ${ }^{2,11,19}$ Kontraindikasi relatif propanolol meliputi asma, gagal jantung kongestif, diabetes 
melitus, blok atrioventrikular, dan penyakit paru ubstruktif kronik (PPOK). Efek samping propanolol meliputi pusing, kelelahan, impotensi, bradikardia, perubahan kadar gula darah, dan hipotensi. ${ }^{2,10,11}$

Primidone (Mysoline) merupakan pengobatan lini pertama pada pasien usia tua dan pasien kontraindikasi $\beta$-bloker. Primidone adalah antikonvulsan yang dimetabolisme menjadi feniletilmalonamid (PEMA) dan fenobarbital. Pemberian dimulai dari dosis kecil 62,5-250 mg/hari dan ditingkatkan perlahan-lahan sampai $750 \mathrm{mg} /$ hari setara dengan propanolol 120 $\mathrm{mg} / \mathrm{hari}$, efektif mengurangi tremor ekstremitas pada tremor esensial. Efek samping primidone dapat ditemukan bahkan pada awal terapi, meliputi sedasi, kelelahan, nausea, vomitus, ataksia, malaise, pusing, konfusi, vertigo, dan reaksi toksik akut. Kombinasi propanolol dan primidone direkomendasikan jika pengobatan dengan salah satunya tidak adekuat. ${ }^{3,4,10,11,19}$

Pengobatan lini kedua pada tremor esensial meliputi gabapentin, topiramate, clozapine, benzodiazepine kerja lama (Clozepam), dan injeksi lokal toksin botulinum., ${ }^{2,10,11,19}$ Pada kasus tremor esensial berat yang resisten terhadap obatobatan, dapat dilakukan tindakan bedah meliputi stimulasi otak frekuensi tinggi (Deep brain stimulation, DBS) dan thalamothom. ${ }^{2,4,11,12}$

\section{Tremor Parkinson}

Penyakit Parkinson merupakan penyebab tremor tersering kedua pada orang dewasa. Tremor ini merupakan tremor istirahat pill rolling, fleksi-ekstensi siku, atau pronasi-supinasi lengan dengan frekuensi $4-6 \mathrm{~Hz}$ dan amplitudo sedang yang dimulai pada salah satu sisi tubuh (tangan, kepala, badan, rahang, bibir), biasanya pada lengan bagian distal dan dapat bertahan selama bertahun-tahun sebelum sisi tubuh kontralateral ikut mengalami tremor. ${ }^{6,7,12}$

Penyakit Parkinson disebabkan oleh degenerasi lambat saraf-saraf dopaminergik inhibitor dan eksitatorik pada area substansia nigra pars kompakta, yang menyebabkan nukleus intermedia ventral di talamus menjadi overaktif, sehingga menyebabkan tremor. ${ }^{6}$ Penyakit Parkinson memiliki tanda-tanda neurologis lain seperti bradikinesia, rigiditas, dan instabilitas postural. Gejala tremor pada penyakit Parkinson sering ditemukan setelah usia 50 tahun, namun terdapat onset awal, yaitu sekitar usia 20 tahun, dimana biasanya diawali dengan tremor esensial. Sekitar 50\% pasien juga mengalami tremor postural dengan frekuensi yang sama atau lebih tinggi daripada tremor istirahat. ${ }^{4,7,13}$

Penatalaksanaan tremor Parkinson berupa penggunaan obat-obatan hanya dibutuhkan jika termor ini disertai gejalagejala yang lain dari penyakit Parkinson. Antiparkinson diberikan mulai dari dosis kecil dan dinaikkan bertahap sesuai frekuensi dan kekuatan tremor. Pengobatan lini pertama yaitu antikolinergik seperti benztropine mesylate, biperiden dosis 1-12 mg dinaikkan 2 mg tiap minggu, triheksifenidil dengan dosis 1-10 mg dinaikkan $2 \mathrm{mg}$ tiap minggu, terutama pada usia muda. Efek samping meliputi retensi urin, konstipasi, konfusi terutama pada usia lanjut, halusinasi, mulut kering, glaukoma, defisit memori. ${ }^{4,9}$ Jika pengobatan antikolinergik tidak adekuat, dapat diberikan glutamat agonis seperti amantadine dengan dosis 100-300 mg/hari. Jika dosis toleransi maksimum terhadap kedua obat tersebut tidak berhasil, obat tersebut dihentikan dan diganti dengan levodopa-carbidopa 50-600 mg/hari dibagi dalam 2-3 dosis per hari dengan dosis awal $50 \mathrm{mg} /$ hari. Pada pemberian levodopacarbidopa (Sinemet), kadar obat dalam darah berfluktuasi sehingga menyebabkan fenomena on-off dan terjadinya diskinesia, sehingga sebaiknya diberikan dosis kecil pada interval pengobatan. Dopamin agonis seperti bromokriptin 5-20 $\mathrm{mg} / \mathrm{hari}$ dinaikkan $5 \mathrm{mg} /$ minggu dapat membantu mengurangi fenomena on-off dan menurunkan dosis levodopa. ${ }^{3,4,9,21}$ Pemberian neuroleptik atipikal berupa clozapine 12,5-75 mg/hari dinaikkan 12,5 
mg/hari juga dapat mengurangi tremor istirahat. Efek samping meliputi sedasi, agranulositosis, dan leukopenia, sehingga membutuhkan hitung jenis darah regular. Propanolol dapat diberikan sebagai terapi tambahan pada tremor postural dan kinetic pada penyakit Parkinson. ${ }^{2,4}$ Pembedahan fungsional dilakukan pada tremor yang resisten terhadap obat-obatan, meliputi thalamotomy (thermocoagulation) dan DBS $^{2,3,4,20}$

\section{Tremor serebelaris}

Tremor serebelaris merupakan tremor aksi dengan frekuensi kurang dari $5 \mathrm{~Hz}$, unilateral atau bilateral dan tidak ditemukan pada keadaan istirahat. Ada dua bentuk tremor serebelaris yaitu tremor postural $(2-4 \mathrm{~Hz})$ dan tremor kinetik (3-5 $\mathrm{Hz}){ }^{2,4}$

Penatalaksanaan tremor serebelaris sangat sulit. Beberapa penelitian terbuka mengatakan pemberian clonazepam, carbamazepine, dan ondansetron (antagonis serotonergik) menunjukkan perbaikan. Terapi simtomatik yang paling baik ialah thalamotomy dan DBS pada ventral intermediate nucleus of the thalamus (Vim). Terapi bedah hanya memperbaiki tremor saja sedangkan gejala ataksia tidak dapat dihilangkan. 2,4,15

\section{Tremor ortostatik primer}

Tremor ortostatik primer merupakan salah satu jenis tremor esensial, frekuensi 13-18 Hz, amplitude rendah, yang mengenai tungkai dan badan, disertai derajat sinkronisasi yang tinggi antara ekstremitas atas dan bawah. Tremor ortostatik menyebabkan ketidakstabilan pada saat berdiri dan berkurang dengan berjalan, duduk, atau bersandar., ${ }^{2,4}$ Pada pemeriksaan fisik ditemukan desiran halus pada otot gastronemius atau otot kuadrisep yang pada auskultasi dapat terdengar seperti suara helikopter di kejauhan. Diagnosis klinis tremor ortostatik primer dapat dikonfirmasi dengan pemeriksaan EMG permukaan yang memperlihatkan tremor $13-18 \mathrm{~Hz}$ pada otot tungkai. 2,6,13
Pengobatan lini pertama pada tremor ortostatik primer ialah gabapentin 18002400 mg/hari. Selain itu, clonazepam 0.5-2 $\mathrm{mg} / \mathrm{hari}$ dan levodopa-carbidopa juga sangat efektif dalam mengobati tremor ini, tetapi clonazepam tidak selalu dapat ditoleransi dengan baik. Alternatif lainnya meliputi primidone, fenobarbital, asam valproate, carbamazepine, ethosuximide, baclofen, dan acetazolamide. Pencegahan berdiri lama dapat membantu pada beberapa pasien. Pemberian propanolol dan alkohol biasanya tidak efektif. 2,3,4,15

\section{Tremor distonia}

Tremor distonia merupakan tremor yang terjadi pada bagian tubuh yang dipengaruhi distonia seperti tangan, kepala, dan leher. Tremor bersifat irregular dan menyentak-nyentak (jerky) dengan frekuensi bervariasi $(<7 \mathrm{~Hz})$ dan biasanya menghilang saat istirahat. Etiologi tremor ini tidak diketahui, namun diduga melibatkan ganglia basalis. ${ }^{2,4,9}$

Penatalaksanaan tremor distonia dilakukan untuk mengobati penyebab distonia, biasanya melalui injeksi toksin botulinum untuk tremor kepala 40-400 unit pada otot yang terkait dan untuk tangan dengan dosis 50-100 unit pada otot agonis/antagonis yang mengalami tremor. Jika tremor tidak membaik, dapat diberikan antikolinergik seperti triheksifenidil dan baclofen sebagai anti-distonik atau benzodiazepine. Alternatif lainnya meliputi propanolol, primidone, levodopa, neuroleptik, carbamazepine, dan tetrabenazine. Pada kasus tremor yang berat, dapat dilakukan DBS pada globus palidus atau talamus ventrolateral dan rhizotomy dorsal selektif. $^{2,4,9,12,15}$

\section{Tremor Holmes}

Tremor Holmes (tremor rubra, tremor mesensefalon, tremor thalamus, mioritmia, sindrom Benedikt) merupakan kelainan gerakan yang jarang terjadi. Kriteria untuk menentukan tremor Holmes ialah: adanya tremor istirahat dan tremor intensi; ${ }^{4,8}$ frekuensi rendah biasanya $<4.5 \mathrm{~Hz} ;^{4,15}$ dan 
bila diketahui waktu terjadinya lesi (misalnya trauma serebrovaskular), biasanya waktu antara terbentuknya lesi sampai timbulnya tremor antara 2 minggu sampai 2 tahun. ${ }^{4,8}$

Tremor Holmes terjadi pada saat istirahat, posisi tertentu, atau selama gerakan menuju sasaran, digambarkan sebagai tremor istirahat yang disertai dengan komponen kinetik dan postural, biasanya mengenai otot proksimal dan distal unilateral. ${ }^{2,4,15}$ Dasar patofisiologi tremor Holmes ialah adanya gangguan hubungan antara serebelo-talamikus dan sistem nigrostriatal dopaminergik. ${ }^{4}$

Penatalaksanaan tremor Holmes sulit dilakukan. Pengobatan lini pertama yang diberikan ialah obat dopaminergik seperti bromocriptine 5-20 mg dinaikkan 5 $\mathrm{mg} / \mathrm{minggu}$, lisuride 0,1-1,2 mg dinaikkan $0,1 \mathrm{mg} / \mathrm{minggu}$ terutama pada tremor istirahat. Alternatif lainnya meliputi antikolinergik dan levodopa pada tremor istirahat, beta-bloker seperti propanolol 30$240 \mathrm{mg}$ dinaikkan $30 \mathrm{mg} / \mathrm{minggu}$ atau primidone 62,5-500 mg dinaikkan 125 $\mathrm{mg} /$ hari pada tremor aksi. Terapi berupa Clonazepam 0.5-6 mg dinaikkan 0,5 $\mathrm{mg} / \mathrm{hari}$ dan clozapine 12,5-75 mg dinaikkan 12,5 $\mathrm{mg} / \mathrm{har}$ ) juga dapat diberikan sebagai alternatif. Pada beberapa kasus resisten, pembedahan (thalamic DBS) dapat dilakukan. ${ }^{2,4,15}$

\section{Tremor induksi obat dan tremor intoksikasi}

Tremor induksi obat meliputi seluruh jenis tremor tergantung pada obat dan individual pasien. Jenis tremor yang paling sering dijumpai adalah tremor fisiologis meninggi dengan frekuensi diatas $6 \mathrm{~Hz}$. Tremor ini timbul akibat penggunaan obat simpatomimetik terutama agonis- $\beta_{2}$ (pseudoefedrin, adrenalin, bronkodilator, teofilin, kafein, dopamin, teeine); ${ }^{2,4,9}$ siklosporin, alcohol withdrawal, litium (tremor postural ringan pada tangan, frekuensi 8-12 $\mathrm{Hz}$ ), dan antidepresan trisiklik atau fluoxetine (Prozac), benzodiazepine putus obat, hipoglikemi pada penggunaan insulin, dan asam valproat (3-12 bulan sejak mulai terapi). ${ }^{2,4,7-9}$ Tardive tremor merupakan tremor frekuensi rendah (3-5 Hz), biasanya postural tetapi dapat terjadi pada saat istirahat atau selama pergerakan. Tremor ini disebabkan penggunaan jangka panjang obat-obat neuroleptik, dan biasanya risiko tinggi pada pasien wanita dengan tremor esensial dan usia tua. ${ }^{4,9}$

Penatalaksanaan tremor induksi obat dan intoksikasi biasanya dengan menghentikan pemberian obat-obat yang dapat menginduksi tremor. Pada kasus dimana tremor tidak membaik walaupun obat-obat tersebut telah dihentikan, dapat diberikan beta-bloker seperti propanolol, sotalol, atau metoprolol dosis rendah, triheksifenidil, atau clozapine., ${ }^{2,3,15}$

\section{Tremor neuropatik}

Tremor neuropatik merupakan salah satu manifestasi neuropati perifer. Tremor ini lebih sering dijumpai pada neuropati demielinisasi daripada aksonal, terutama pada polineuropati demielinisasi kronik akibat antibodi IgM terhadap glikoprotein yang berhubungan dengan mielin (MAG), polineuropati paraproteinemia, neuropati motorik dan sensorik, dan sindrom Guillain-Barre kronik. Karakteristik tremor ini menyerupai tremor esensial, bertambah parah saat pasien mempertahankan tangan mendekati target, dan hanya terdapat pada anggota gerak yang terkena neuropati. Bentuknya lebih irregular daripada tremor esensial. $2,3,8,15$

Penatalaksanaan tremor ini dengan mengobati penyebab neuropati. Pemberian beta-bloker seperti propanolol efektif pada tremor yang berhubungan dengan chronic inflammatory demyelinating polyneuropathy (CIDP), neuropati sensorik dan motorik herediter (HMSN) tipe I, atau sindrom Guillain-Barre. Primidone dengan dosis yang sama pada tremor esensial dan clonazepam juga dapat diberikan. ${ }^{2,3,15}$

\section{Tremor psikogenik}

Tremor psikogenik sering disebut 
tremor fungsional atau tremor histerikal, ditandai dengan: onset tiba-tiba dan/atau remisi; gabungan antara tremor postural/intensi dan tremor istirahat; amplitudo tremor berkurang jika dikacaukan dan meningkat jika diberi beban; perubahan frekuensi tremor selama gerakan volunter pada tangan kontralateral; aktivasi kembali tanda tremor psikogenik pada pergelangan tangan bervariasi; dan riwayat penyakit somatisasi. ${ }^{4,9}$ Direkomendasikan fisioterapi dekontraksi pada otototot selama gerakan volunter. Psikoterapi dan propanolol dengan dosis sedang atau tinggi dapat diberikan untuk desensitisasi otot untuk mempertahankan mekanisme klonus pada pasien tremor ini. ${ }^{3,15}$

Tabel 3. Pilihan pengobatan pada sindrom-sindrom tremor ${ }^{2}$

\begin{tabular}{|c|c|c|c|c|c|c|c|c|}
\hline & $\begin{array}{l}\text { Tremor } \\
\text { esensial }\end{array}$ & $\begin{array}{l}\text { Tremor } \\
\text { ortostatik }\end{array}$ & $\begin{array}{l}\text { Task- } \\
\text { spesific } \\
\text { tremor }\end{array}$ & $\begin{array}{l}\text { Tremor } \\
\text { distonia }\end{array}$ & $\begin{array}{l}\text { Tremor } \\
\text { Parkinson }\end{array}$ & $\begin{array}{l}\text { Tremor } \\
\text { serebelaris }\end{array}$ & $\begin{array}{l}\text { Tremor } \\
\text { Holmes }\end{array}$ & $\begin{array}{l}\text { Tremor } \\
\text { neuropatik }\end{array}$ \\
\hline Propanolol & $\mathrm{X}^{*}$ & & $\mathrm{X}$ & $\mathrm{X}$ & $\mathrm{X}$ & & $\mathrm{X}$ & $\mathrm{X}$ \\
\hline Primidone & $\mathrm{X}^{*}$ & $\mathrm{X}$ & $\mathrm{X}$ & $\mathrm{X}$ & & & & \\
\hline Gabapentin & $\mathrm{X}$ & $\mathrm{X}$ & & & & & & \\
\hline Alprazolam & $\mathrm{X}$ & & & & & & & \\
\hline Topiramate & $\mathrm{X}$ & & & & & & & \\
\hline Clozapine & $\mathrm{X}$ & & & & $\mathrm{X}$ & & $\mathrm{X}$ & \\
\hline $\begin{array}{l}\text { Toksin } \\
\text { botulinum }\end{array}$ & $\mathrm{X}$ & & $\mathrm{X}$ & $\mathrm{X}^{*}$ & & & & \\
\hline Carbamazepine & & & & $\mathrm{X}$ & & $\mathrm{X}$ & & \\
\hline Clonazepam & & $\mathrm{X}^{*}$ & & $\mathrm{X}$ & & $\mathrm{X}$ & $\mathrm{X}$ & $\mathrm{X}$ \\
\hline Phenobarbital & & $\mathrm{X}$ & & & & & & \\
\hline Asam valproat & & $\mathrm{X}$ & & & & & & \\
\hline Levodopa & & $\mathrm{X}$ & & $\mathrm{X}$ & $\mathrm{X}^{*}$ & & $\mathrm{X}^{*}$ & \\
\hline $\begin{array}{l}\text { Agonis } \\
\text { dopamine }\end{array}$ & & $\mathrm{X}$ & & & $\mathrm{X}^{*}$ & & $\mathrm{X}^{*}$ & \\
\hline Antikolinergik & & & $\mathrm{X}$ & $\mathrm{X}$ & $\mathrm{X}$ & & $\mathrm{X}$ & \\
\hline Tetrabenazine & & & & $\mathrm{X}$ & & & & \\
\hline Pembedahan & $\mathrm{X}$ & & & $X$ & $\mathrm{X}$ & $\mathrm{X}$ & $\mathrm{X}$ & \\
\hline
\end{tabular}

\section{SIMPULAN}

Penatalaksanaan tremor tergantung pada tingkat keparahan dan etiologi yang mendasari terjadinya tremor. Pengobatan dilakukan untuk mengurangi gangguan fungsional dan meningkatkan kualitas hidup. Oleh karena itu, pengobatan biasanya dilakukan saat tremor mulai mengganggu aktivitas sehari-hari, atau membuat pasien rendah diri. Penanganan bedah hanya dibatasi pada kasus-kasus yang gagal dengan obat-obatan.

\section{DAFTAR PUSTAKA}

1. Grimaldi G, Manto M. Neurological tremor: sensors, signal processing and emerging applications. Sensors 2010;10:1399-422.
2. Berendse HW, van Laar T. Tremor. In: Wolters EC, van Laar T, editors. Parkinsonism and related disorders. Amsterdam: University Press, 2007: p. 309-22.

3. Ropper AH, Phil RHBD. Adams and Victor's Principles of Neurology (8th ed.). New York: McGraw-Hill, 2005; p. 80-6.

4. Deuschl G, Volkmann J, Raethjen J. Tremors: differential diagnosis, pathophysiology, and therapy. In: Jankovic J, Tolosa E, editors. Parkinson's Disease and Movement Disorders (5th ed.). Philadelphia: Williams \& Wilkins, 2007; p. 298-311.

5. Haerer AF. De Jong's the Neurologic Examination (5th ed.). Philadelphia: J.B. Lippincott, 1992; p. 402-6.

6. Charles PD, Esper GJ, Davis TL. 
Classification of tremor and update on treatment. Am Fam Physician. 1999;315:1565.

7. Smaga S. Tremor. Am Fam Physician. 2003;68:1545-52,1553.

8. Bain PG. The management of tremor. J Neurol Neurosurg Psychiatry. 2002;72(Suppl I):i3-i9.

9. Bhagwath G, editor. Tremors in elderly persons: clinical features and management. Kansas City, Missouri Area: Turner White Communication, 2001; p. 31-7, 49.

10. Deuschl G, Lorenz D. Essential tremor. In: Gasser, editor. Essential Tremor. Niemannsweg: University of Kiel, 2003.

11. Zesiewicz TA, Elble R, Louis ED. Practice parameter: therapies for essential tremor: report of the Quality Standards Subcommittee of The American Academy of Neurology. Neurology. 2005;64:2008-20.

12. Nahab FB, Peckham E, Hallett $M$. Essential tremor, deceptively simple. Pract Neurol. 2007;7:222-33.

13. Zesiewicz TA, Hauser RA. Diagnosis and treatment of tremor. Ann Neurol.
1997;41(1):58-64.

14. Kassubek J, Landwehrmever GB, Lucking CH. Post Ischemic Holmes tremor investigated by FDG- and $\mathrm{H}_{2} \mathrm{O}$ PET. J Rad. 2003;55:1-8.

15. Louis ED. Fascinating rhythm: recognizing and treating tremor. Ann Neurol. 2007;22:833-8. 14

16. Pietro M, Pearson, Rowland LP, editors. Merritt's Neurology Handbook (2nd ed.). Philadelphia: Williams \& Wilkins, 2006; p. 475-8.

17. Benito-Leon J, Louis ED. Essential tremor: emerging views of a common disorder. Neurology. 2006;2:666-78.

18. Lullmann H, Mohr K, Ziegler A, editors. Color Atlas of Pharmacology (2nd ed.). New York: Thieme New York, 2000; p. 92-4.

19. Louis ED. Essential tremor. N Engl J Med. 2001:345:12.

20. Marks WJ. Overview of deep brain stimulation, indications, \& patient selection. Ann Neurol. 2007;69:681-8.

21. Ropper AH, Phil RHBD. Adams and Victor's Principles of Neurology (8th ed.). New York: McGraw-Hill, 2005; p. 921-4. 